\title{
PROFIL KETERAMPILAN BERPIKIR KRITIS SISWA MENGGUNAKAN PEMBELAJ ARAN DISCOVERY INQUIRY PADA KONSEP KOLOID
}

\author{
Salbiah ${ }^{1}$ \\ ${ }^{1}$ SMK Negeri 1 Cikarang Utara Bekasi \\ Perum Grand Cikarang City Blok E 18 Rt. 10 Rw. 15. Kode Pos, 17530 \\ E-mail: salbiahspdkimia@gmail.com
}

\begin{abstract}
ABSTRAK
Tujuan penelitian ini untuk menganalisis keterampilan berpikir kritis siswa setelah pembelajaran. Metode penelitian kelas digunakan dalam penelitian ini untuk mememeperbaiki kualitas pembelajaran di kelas melalui penerapan pembelajaran discovery inquiry. Subjek penelitian ini adalah 42 siswa kelas XI IPA di Salah satu SMA di Jawa Barat. Instrumen yang digunakan adalah deskripsi pembelajaran, lembar kerja siswa, tes keterampilan berpikir kritis, dan pedoman observasi. Hasil penelitian menunjukkan keterampilan berpikir kritis siswa setelah pembelajaran secara keseluruhan termasuk pada kategori sangat baik nilai (81). Pencapaian keterampilan berpikir kritis tertinggi pada indikator mengidentifikasi contoh (89) dan terendah pada indikator membuat kesimpulan (72). Kelompok prestasi tinggi pencapaiannya tertinggi (90), sedangkan kelompok prestasi rendah pencapaiannya paling rendah (73).
\end{abstract}

Kata Kunci: pembelajaran discovery inquiry, keterampilan berpikir kritis, konsep koloid

\begin{abstract}
The purpose of this study is to analyze students' critical thinking skills after a learning process in colloid concept. Classroom research methods was used in this study to improve learning quality in the classroom through the application of discovery inquiry learning. The subject of this research was 42 students of science class grade $\mathrm{XI}$ in acertain highschool in West Java. The instruments used were learning descriptions, student worksheet, critical thinking skills tests, and observation guidelines. The results showed that students' critical thinking skills after overall learning process included in the category of excellent value (81). The achievement of the highest critical thinking skills was on example identification indicators (89) and the lowest was on the indicator of making conclusion (72). The highest achievement group showed highest improvement (90), while the lowest achievement group was the lowest (73).
\end{abstract}

Keywords: Discovery Inquiry Learning, Critical Thinking Skills, Colloid Concept. DOI: http://dx.doi.org/10.15575/jta.v2i1.1367

\section{PENDAHULUAN}

Kimia merupakan ilmu yang dipenuhi dengan fenomena alam yang menarik, kegiatan eksperimen yang menarik, dan pengetahuan yang bermanfaat untuk memahami sifat dan proses terjadinya alam semesta (Roehrig, 2004). Sistem koloid merupakan salah satu konsep kimia yang menerangkan fenomena alam dan banyak penerapannya dalam kehidupan sehari-hari, misalnya: pembentukan pelangi setelah hujan, penjernihan air, pemutihan gula tebu, pembuatan lateks dan lain sebagainya (Achmad, 2001:213). Konsep ini perlu dieksplorasi oleh siswa melalui konstruksi pengetahuan secara aktif (Suyanti, 2010) 
Berdasarkan hasil wawancara terhadap salah satu guru kimia di lokasi penelitian, hasil belajar siswa pada konsep Koloid masih rendah, siswa kurang aktif dan merasa terbebani untuk menghafal istilah-istilah dalam konsep koloid. Meskipun telah diberi tugas membaca konsep, siswa belum mampu menjawab pertanyaan yang diberikan dengan baik.

Diduga kondisi tersebut karena terjadi kecenderungan proses pembelajaran masih berpusat pada guru dan siswa kurang diberi kesempatan beraktivitas untuk mengkonstruksi pengetahuannya sendiri. Hal ini sejalan dengan yang dikemukakan oleh Sanjaya (2010:92-93) pada umumnya, sebagian besar guru dalam proses pembelajaran tidak berusaha mengajak berpikir kepada siswa. Guru menganggap, bagi siswa menguasai materi lebih penting dibandingkan dengan mengembangkan kemampuan berpikir. Hal tersebut menyebabkan kemampuan berpikir siswa menjadi kurang terlatih.

Salah satu keterampilan berpikir yang perlu dikembangkan adalah berpikir kritis. Berpikir kritis merupakan suatu proses mental/intelektual berkaitan dengan keterampilan dalam membuat pengertian atau konsep, mengaplikasikan, menganalisis, membuat sintesis, dan mengevaluasi (Scriven dalam Fisher, 2009:10), sehingga selanjutnya dapat diaplikasikan untuk memecahkan masalah, mengambil keputusan, menganalisis asumsi, dan melakukan penelitian (Johnson, 2011:183). Berpikir kritis perlu dikembangkan untuk menganalisis argumen dan memunculkan wawasan serta mengembangkan pola penalaran yang kohesif dan logis (Liliasari, 2003:175). Keterampilan berpikir kritis dapat berkembang bila siswa terlibat aktif dalam pembelajaran aktif (Bonwell \& Eison dalam Duron et al., 2006:165).

Menurut Sund (dalam Arifin, 2000:140) pendekatan discovery inquirydapat melibatkan siswa secara aktif menggunakan proses mentalnya untuk menemukan beberapa konsep dan prinsip materi yang sedang dipelajari. Pendekatan discovery inquiry menekankan dan memberikan kesempatan kepada siswa untuk bereksplorasi dan belajar sendiri (Balim, 2009). Pendekatan discovery inquiry berasal dari keyakinan bahwa siswa memiliki kebebasan untuk belajar dan mempunyai rasa keingintahuan yang tinggi. Penelitian Nurmalinda (2011:57) menunjukan siswa dapat mengembangkan keterampilan berpikir kritis dengan baik pada pembelajaran perkembangan konsep redoks menggunakan pendekatan discovery inquiry. Pada makalah ini dilaporkan profil keterampilan berpikir kritis siswa pada konsep koloid setelah diterapkan pembelajaran discovery inquiry.

\section{METODE PENELITIAN}

Subjek pada penelitian adalah 42 orang siswa di salah satu SMA di Jawa Barat. Data profil keterampilan berpikir kritis diperoleh selama dan setelah menerapkan pembelajaran discovery inquiry. Lembar Kerja Siswa (LKS) digunakan untuk mengembangkan keterampilan berpikir kritis siswa selama pembelajaran berlangsung. LKS memuat dua topik masalah dan disertai tugas dan pertanyaan. Setelah pembelajaran diberikan tes keterampilan berpikir kritis berbentuk uraian (10 butir soal) yang mencakup enam indikator, yaitu: mengemukakan persamaan dan perbedaan, mengidentifikasi contoh, mengidentifikasi kriteria atas jawaban yang mungkin, memberikan penjelasan sederhana, kemampuan memberikan alasan, dan membuat kesimpulan.

\section{HASIL DAN PEMBAHASAN}

Penerapan pembelajaran discovery inquiry ditujukan untuk menjawab Langkah-langkah pembelajaran yang dilakukan sebagai berikut: 1) memberikan stimulasi: dilakukan dengan mengajukan pertanyaan-pertanyaan yang mendorong keingintahuan siswa, mengembangkan kemampuan memprediksi berdasarkan pola-pola fenomena berkaitan dengan kehidupan sehari-hari, 2) merumuskan masalah, siswa diminta membaca dan menganalisis dua 
permasalahan dalam wacana yang disajikan dalam LKS, yaitu: 1) Bagaimana mengolah air sungai yang kotor agar layak digunakan dan dapat memenuhi standar air bersih? dan 2) Bagaimana membedakan sifat antara larutan, koloid, dan suspensi berdasarkan ukuran partikel, efeknya terhadap cahaya dan penampilan fisisnya? Berdasarkan rumusan masalah dan hipotesis yang telah disusunnya, siswa merancang percobaan untuk menjawab permasalahan tersebut. Untuk sampai kepada perancangan percobaan, diberikan pertanyaan-pertanyaan pengarah dan bimbingan dari guru, 3) mengumpulkan data: siswa melakukan percobaan sesuai dengan rancangannya, yaitu percobaan penjernihan air dengan menggunakan prinsip koagulasi dan menyelidiki perbandingan sifat antara larutan, koloid, dan suspensi berdasarkan ukuran partikel dan efeknya terhadap cahaya serta penampilan fisisnya; 4) menganalisis data: siswa melakukan interpretasi dan menghubungkan data dengan teori/prinsipprinsip; 5) memverifikasi: hasil analisis dikaji ulang untuk dibandingkan dengan hipotesis yang telah disusun sebelumnya; dan 6) membuat generalisasi: siswa menarik kesimpulan dan membuat laporan tertulis serta mempresentasikan hasil kerjanya.

Setelah pembelajaran, siswa diberikan tes keterampilan berpikir kritis dengan menggunakan tes uraian. Profil keterampilan berpikir kritis siswa pada setiap indikator berdasarkan kelompok prestasi dapat dilihat pada Tabel 1. Pengelompokan siswa itu berdasarkan rerata hasil belajar siswa dari test formatif untuk materi sebelumnya (materi prasyarat).

Tabel 1. Keterampilan berpikir kritis siswa pada tiap kelompok prestasi untuk tiap indikator

\begin{tabular}{|c|c|c|c|c|c|c|c|c|}
\hline \multirow[b]{2}{*}{ No } & \multirow[b]{2}{*}{ Kelompok Prestasi. } & \multicolumn{6}{|c|}{ Nilai Tiap Indikator } & \multirow{2}{*}{$\begin{array}{c}\text { Nilai } \\
\text { Rata-rata }\end{array}$} \\
\hline & & 1 & 2 & 3 & 4 & 5 & 6 & \\
\hline 1 & Tinggi & 83 & 90 & 90 & 100 & 86 & 90 & 90 \\
\hline 2 & Sedang & 70 & 89 & 89 & 88 & 79 & 65 & 80 \\
\hline 3 & Rendah & 70 & 87 & 75 & 70 & 77 & 60 & 73 \\
\hline & Rata-rata & 74 & 89 & 85 & 86 & 81 & 72 & 81 \\
\hline
\end{tabular}

Keterangan:

1: Mengemukakan persamaan dan perbedaan

2: mengidentifikasi contoh

3: Mengidentifikasi kriteria atas jawaban yang mungkin

4: Memberikan penjelasan sederhana

5: Kemampuan memberikan alasan

6: Membuat kesimpulan

Berdasarkan Tabel 1 di atas, dapat dilihat bahwa secara keseluruhan, rerata nilai keterampilan berpikir kritis untuk semua indikator mencapai nilai 81. Pencapaian nilai ini termasuk tinggi dan memenuhi kriteria ketuntasan minimal (KKM). Urutan pencapaian nilai KBK secara keseluruhan, tertinggi untuk kelompok prestasi tinggi (nilai 90), sedangkan terendah untuk kelompok prestasi rendah (nilai 73).

Pencapaian nilai KBK untuk setiap indikator pada setiap kelompok prestasi bervariasi. Kelompok tinggi pada indikator memberikan penjelasan sederhana mendapatkan nilai tertinggi dengan nilai 100 . Kelompok rendah pada indikator membuat kesimpulan mendapatkan nilai terendah dengan nilai sebesar 60. Adapun pada indikator mengidentifikasi contoh mendapatkan nilai rata-rata tertinggi yaitu sebesar 89 , untuk indikator membuat kesimpulan mendapatkan nilai rata-rata terendah yaitu sebesar 72 .

Keterampilan berpikir kritis pada indikator mengemukakan persamaan dan perbedaan memperoleh nilai secara keseluruhan sebesar 74 dengan kategori baik. Nilai tertinggi diperoleh oleh kelompok tinggi, dengan nilai sebesar 83, dan nilai terendah diperoleh oleh kelompok sedang dan rendah dengan nilai 
sebesar 70. Untuk dapat mengemukakan persamaan dan perbedaan, siswa terlebih dahulu diberikan tabel data percobaan mengenai perbandingan sifat larutan, koloid, dan suspensi.

Berdasarkan sebaran siswa pada indikator ini, siswa kelompok tinggi mampu membedakan tiga campuran yang berbeda berdasarkan tabel data percobaan dengan sangat baik, sedangkan kelompok sedang dan rendah sebagian kecil dari anggotanya dapat membandingkan persamaan dan perbedaan dengan baik namun kurang tepat. Hal ini diduga pada saat proses pembelajaran siswa kelompok sedang dan rendah kurang mampu melakukan penggalian konsep secara maksimal dalam melakukan praktikum efek Tyndall. Sehingga siswa kelompok sedang dan rendah mengalami kesulitan dalam mengerjakan soal pada indikator ini. Padahal soal yang diberikan serupa dengan data percobaan yang telah mereka lakukan pada saat praktikum. Penelitian serupa dilakukan oleh Widyawati (2009:95) pada konsep larutan penyangga di SMA, mengatakan bahwa keterampilan berpikir kritis siswa pada indikator mengemukakan persamaan dan perbedaan untuk siswa kelompok tinggi termasuk kriteria baik, sedangkan siswa kelompok sedang dan rendah termasuk kriteria cukup.

Penyebab rendahnya perolehan nilai siswa kelompok sedang dan rendah diduga juga disebabkan karena guru yang mengajar bukanlah guru kelas, sehingga guru belum mengenal karakteristik siswa pada awal proses pembelajaran dan belum mengetahui apa saja yang dibutuhkan oleh siswa. Padahal siswa sangat perlu bimbingan atau perhatian yang lebih dari guru. Setelah guru mengetahui karakteristik dan kebutuhan siswa, pada pertemuan kedua guru melakukan perbaikan pembelajaran dengan melibatkan siswa dalam setiap kegiatan pembelajaran. Hal ini sesuai dengan pendapat Bonwell dan Eison (dalam Duron et al., 2006:165) dengan melibatkan siswa dalam proses pembelajaran, keterampilan berpikir kritis siswa akan terlatih dengan sendirinya.
Keterampilan berpikir kritis kedua yaitu indikator menyebutkan contoh mendapatkan nilai rata-rata tertinggi yaitu sebesar 89 dengan kategori sangat baik. Tingginya nilai siswa dari seluruh kelompok prestasi sejalan dengan hasil penelitian Kaswan (2005:74) mengenai kegiatan laboratorium berbasis inkuiri pada konsep koloid, bahwa keterampilan berpikir kritis siswa mengalami peningkatan pada indikator mengidentifikasi contoh dengan kategori peningkatan sangat baik. Hal ini karena pada saat pembelajaran, siswa melakukan praktikum mengenai efek Tyndall terhadap campuran garam, susu, dan air sungai yang keruh. Kemudian pada saat tes keterampilan berpikir kritis, siswa diminta untuk mengidentifikasi tiga contoh selain dari contoh yang mereka pelajari pada saat praktikum. Sehingga siswa tidak mengalami kesulitan menjawab soal pada indikator ini. Hal ini terbukti dari hasil analisis sebaran, hampir seluruh siswa dari kelompok tinggi, sedang, dan rendah dapat menjawab soal dengan sangat baik. Hal ini menggambarkan bahwa siswa sudah mampu menghubungkan hasil pengamatan dengan fenomena baru yang diberikan setelah pembelajaran. Hal ini sejalan dengan pernyataan Hudojo (dalam Trianto, 2009:19) mengemukakan bahwa lingkungan belajar yang konstruktif salah satunya adalah menyediakan pengalaman belajar yang mengaitkan pengetahuan baru dengan pengetahuan yang telah dimiliki siswa sehingga belajar merupakan proses pembentukan pengetahuan.

Keterampilan berpikir kritis ketiga yaitu indikator mengidentifikasi kriteria atas jawaban yang mungkin mendapatkan nilai rata-rata sebesar 85 dengan kategori sangat baik. Untuk dapat mengidentifikasi kriteria atas jawaban yang mungkin, siswa terlebih dahulu diberikan gambar gaya tolak menolak antar partikel koloid. Kemudian siswa diminta untuk memprediksi partikel-partikel tersebut apabila bermuatan sejenis. Berdasarkan sebaran siswa pada indikator ini, siswa kelompok tinggi dan sedang mampu memprediksi partikel-partikel bermuatan sejenis berdasarkan gambar gaya tolak menolak antar partikel koloid dengan sangat baik. Sedangkan sebagian siswa dari 
kelompok rendah mengalami kesulitan dalam memprediksi gambar gaya tolak menolak antar partikel koloid dengan tepat. Sebagian siswa kelompok rendah hanya mampu menjawab bahwa partikel-partikel koloidnya saling tolak menolak. Hal ini terbukti dengan nilai yang diperoleh kelompok rendah sebesar 75 dengan kategori baik.

Hal ini diduga pada saat praktikum mengenai penjernihan air, siswa kelompok rendah kurang teliti dalam mengamati penggumpalan partikel-partikel koloid setelah penambahan tawas ke dalam air sungai yang keruh. Sehingga siswa mengalami kesulitan dalam mengerjakan soal yang berhubungan dengan partikel-partikel koloid. Hal ini sesuai dengan laporan dari Eckschlager (dalam Widyawati, 2009:49) mengungkapkan bahwa siswa sering melakukan kesalahan dalam pengamatan pada saat praktikum, diduga penyebabnya yaitu keterbatasan mata untuk mengamati. Hasil penelitian serupa dilakukan oleh Nurmalinda (2011:57) pada konsep redoks di SMA, mengungkapkan bahwa keterampilan berpikir kritis siswa pada indikator mengidentifikasi kriteria atas jawaban yang mungkin. siswa kelompok tinggi dan sedang paling baik, sedangkan siswa kelompok rendah masih rendah

Keterampilan berpikir kritis keempat yaitu indikator memberikan penjelasan sederhana mendapatkan nilai rata-rata sebesar 86 dengan kategori sangat baik. Untuk dapat memberikan penjelasan sederhana, siswa terlebih dahulu diberikan stimulus melalui soal cerita mengenai proses pencucian dengan sabun atau detergen. Kemudian siswa diminta untuk menjelaskan fungsi sabun atau detergen pada proses pencucian tersebut. Berdasarkan sebaran siswa pada indikator ini, siswa kelompok tinggi dan sedang mampu menjelaskan fungsi sabun atau detergen pada proses pencucian dengan sangat baik, sedangkan sebagian kecil siswa dari kelompok rendah dapat menjelaskan fungsi sabun atau detergen pada proses pencucian dengan baik namun kurang tepat. Hal ini terbukti dengan nilai yang diperoleh kelompok rendah sebesar 70 dengan kategori baik. Hasil penelitian serupa dilakukan oleh Firdaus (2011) pada konsep koloid terhadap siswa MAN Cigugur Kuningan, dimana keterampilan berpikir kritis siswa pada indikator memberikan penjelasan sederhana kelompok tinggi dan sedang mengalami peningkatan dengan kategori sangat baik, sedangkan siswa rendah dalam kategori cukup.

Tingginya nilai siswa diduga pada saat pembelajaran siswa mampu menjelaskan peristiwa tumpahnya minyak ke dalam wadah yang berisi air yang kemudian ditambahkan sabun colek ke dalamnya lalu dilakukan pengadukan. Dapat terlihat bahwa peristiwa yang diberikan pada saat pembelajaran dengan soal cerita pada tes keterampilan berpikir kritis konteksnya hampir mirip. Hal ini bertujuan agar siswa dapat terlatih dalam mengidentifikasi suatu permasalahan dalam mengerjakan soal. Sejalan dengan Costa (dalam Akhyani, 2008) mengungkapkan bahwa dalam melatih keterampilan berpikir kritis perlu dilakukan secara berulang-ulang sambil memberikan saran dan perbaikan pada hasil berpikir kritis siswa.

Keterampilan berpikir kritis kelima yaitu indikator kemampuan memberikan alasan mendapatkan nilai rata-rata sebesar 81 dengan kategori sangat baik. Indikator kemampuan memberikan alasan pada LKS juga mendapatkan nilai yang tinggi yaitu sebesar 78 dengan kategori baik. Untuk dapat menjawab indikator kemampuan memberikan alasan, siswa terlebih dahulu diberikan stimulus melalui soal cerita mengenai proses memasak masakan bersantan. Kemudian siswa diminta untuk memberikan alasan mengapa masakan bersantan ditambahkan beberapa tetes larutan tepung maizena.

Berdasarkan hasil analisis sebaran, siswa kelompok tinggi mampu memberikan alasan penambahan larutan tepung maizena ke dalam masakan bersantan dengan sangat baik. Hal ini dikarenakan pada proses pembelajaran, mayoritas siswa dari kelompok tinggi berusaha untuk mengembangkan daya pikir atau penalaran maupun pemahaman 
yang mereka miliki untuk digunakan dalam memberikan alasan pada suatu permasalahan. Pernyataan tersebut sesuai dengan pendapat Schafersman (dalam Akhyani, 2008:81), bahwa seseorang yang berpikir kritis dapat memberikan alasan yang logis terhadap informasi yang dikumpulkan, membuat keputusan yang dapat dipercaya tentang dunia yang memungkinkan seseorang dapat berhasil dalam kehidupannya. Penekanan aspek pemahaman dan pengembangan keterampilan berpikir kritis dapat membantu daya ingat siswa terhadap konsep-konsep dan prinsip-prinsip yang dipelajarinya.

Sebagian kecil siswa dari kelompok sedang dan rendah dapat memberikan alasan dengan baik namun kurang tepat. Ini menunjukkan, beberapa siswa dari kelompok rendah masih lemah dalam menghubungkan antar konsep dan prinsip, dan memberikan argumentasi mengenai penambahan larutan tepung maizena ke dalam masakan bersantan. Temuan yang sama oleh Nurmalinda (2011) keterampilan berpikir kritis siswa kelompok rendah termasuk kriteria kurang.

Keterampilan berpikir kritis keenam yaitu indikator membuat kesimpulan mendapatkan nilai rata-rata sebesar 72 dengan kategori baik. Dengan melakukan praktikum, keterampilan berpikir siswa dapat terlatih dan pengetahuan yang didapatkan siswa akan lebih tahan lama (Suyanti, 2010). Siswa lebih mudah menarik kesimpulan dari pembelajaran yang telah dilakukan mengenai penjernihan air kotor dan perbedaan antara larutan, koloid, dan suspensi. Ini menunjukkan bahwa melalui kegiatan praktikum dapat meningkatkan antusiasme terhadap sains, melatih keterampilan berpikir, menghadapi masalah, dan berlatih menanamkan sikap positif pada diri siswa (Sari, dkk, 2016). Hal serupa diungkapkan oleh Arifin (2000) mengemukakan bahwa mempelajari IPA kurang berhasil apabila tidak ditunjang dengan kegiatan laboratorium.

\section{KESIMPULAN}

Berdasarkan hasil penelitian yang dilakukan diperoleh kesimpulan yaitu secara keseluruhan keterampilan berpikir kritis siswa setelah pembelajaran discovery inquiry pada konsep koloid termasuk kategori sangat baik. Pencapaian keterampilan berpikir kritis tertinggi pada indikator mengidentifikasi contoh dan terendah pada indikator membuat kesimpulan. Kelompok prestasi tinggi pencapaiannya tertinggi, sedangkan kelompok prestasi rendah pencapaiannya paling rendah.

Berdasarkan hasil penelitian dan pembahasan serta kesimpulan yang telah dikemukakan di atas, maka saran yang diajukan yaitu guru yang menggunakan pendekatan discovery inquiry dalam proses pembelajaran harus melatih siswa untuk menghubungkan data hasil praktikum dengan konsep yang ada, menemukan pola-pola dalam data hasil pengamatan, serta harus dapat menerapkan pada situasi yang baru, sehingga siswa akan lebih terampil dalam menarik kesimpulan.

\section{DAFTAR PUSTAKA}

Akhyani, A. 2008. Model Pembelajaran Kesetimbangan Kimia Berbasis Inkuiri Laboratorium Untuk Meningkatkan Penguasaan Konsep dan Keterampilan Berpikir Kritis Siswa SMA. Tesis. Bandung. Tidak diterbitkan.

Arifin, M., dkk. 2000. Strategi Belajar Mengajar Kimia. Bandung: Universitas Pendidikan Indonesia.

Balım, A., G. (2009). The Effects of Discovery Learning on Students' Success andInquiry Learning Skills. Eurasian Journalof EducationalResearch, 35, 120.

Duron, R., Limbach, B., dan Waugh, W. 2006. "Critical Thinking Framework For Any Discipline". International Journal of Teaching and Learning in Higher Education. 17, (II), 160-166. 
Firdaus, A. 2011. Pengembangan Keterampilan Berpikir Kritis Siswa Melalui Metode Pembelajaran RBL (Resource Based Learning) Pada Konsep Koloid. Skripsi. Bandung: UIN. Tidak diterbitkan.

Fisher, Alec. 2009. Berpikir Kritis Sebuah Pengantar. Terjemahan oleh Benyamin Hadinata. Jakarta: PT. Gelora Aksara Pratama.

Kaswan. 2005. Peningkatan Pemahaman Konsep dan Keterampilan Berpikir Kritis Siswa Melalui Kegiatan Laboratorium Berbasis Inkuiri pada Pokok Bahasan Rangkaian Listrik Arus Searah. Tesis UPI. Bandung. Tidak diterbitkan.

Liliasari. 2003. "Peningkatan Mutu Guru dalam Keterampilan Berpikir Tingkat Tinggi Melalui Model Pembelajaran Kapita Selekta Kimia Sekolah Lanjutan". Jurnal Pendidikan Matematika dan Sains. 3,(VIII), 174-181

Mulyasa, E. 2010. Kurikulum Tingkat Satuan Pendidikan. Bandung: PT. Remaja Rosdakarya.

Nurmalinda. 2011. Analisis Keterampilan Berpikir Kritis Siswa Kelas $X$ pada Pembelajaran Perkembangan Konsep Redoks Menggunakan Metode Discovery Inquiry. Tesis UPI. Bandung. Tidak diterbitkan.

Roehrig, Gillian H. 2004. Inquiry Teaching ini High School Chemistry Classrooms: The Role of Knowledge and Beliefs. Journal of Chemical Education. 81, (10), 15101516.

Sari, Ratnasari dan Ida Farida. 2014. Pengembangan Sikap Kreatif Siswa Pada Praktikum Penjernihan Air. EduChemia. 1(2)

Sanjaya, Wina. 2010. Strategi Pembelajaran Berorientasi Standar Proses Pendidikan. Bandung: Kencana Prenada Media.
Suyanti, Retno Dwi. 2010. Strategi Pembelajrana Kimia. Medan: Graha IImu

Trianto. 2009. Mendesain Model Pembelajaran Inovatif-Progresif, Konsep Landasan dan Implementasinya pada Kurikulum Tingkat Satuan Pendidikan (KTSP). Jakarta: Kencana

Widyawati, I. 2009. Pendekatan Pemecahan Masalah Pada Pembelajaran Larutan Penyangga Untuk Meningkatkan Keterampilan Berpikir Kritis Siswa SMA. Tesis. Bandung. Tidak diterbitkan. 